\title{
Analysis of Thermal Performance in Solar Dryer
}

\author{
${ }^{1}$ Nagarajan $S,{ }^{2}$ Prem kumar M \\ ${ }^{I}$ Thermal engineering RVS college of engineering and technology Coimbatore, india \\ ${ }^{2}$ Mechanical Engineering RVS college of engineering and technology Coimbatore, india
}

\begin{abstract}
Solar drying experiments a new type parabolic-shaped solar tunnel dryer was designed and manufactured. Solar dryer consisted of a flat-plate solar collector and a drying tunnel. The collector and the drying tunnel were covered with polycarbonate plates to reduce heat losses and placed in series. Heated air in solar air collector was forced through Grapes by DC-fans driven by $15 \mathrm{~W}$ solar cell modules. The total area of the collector was $108 \mathrm{~m}^{2}$. During the drying period, drying air temperature, relative humidity, air flow rates, solar radiation, and lose of mass were measured at different parts of the dryer for every 10 minutes. To investigate its performance, the dryer was used to dry $1 \mathrm{~kg}$ of Grapes. The dryer could be used for Grapes of $75 \%(w b)$ moisture content, and they could be dried within 2-3 days, with 7\% (wb) remaining moister. The products being dried in the dryer got the heat from both the sunlight and the collectors. the temperature of the drying air was varied between $35-75^{\circ} \mathrm{C}$, depends on the weather conditions
\end{abstract}

\section{Introduction}

Drying is one of the most used methods for product preservation, and as a result, it adds higher value to the products. A dryer can achieve this purpose by supplying more heat which in turn increases the vapor pressure of the moisture in the product, reduces relative humidity of the air, then increases its moisture loading capacity and ensures sufficiently low equilibrium moisture content.

Solar energy can be used as an important and environmental compatible source of renewable energy. The use of solar energy for drying effectively reduces the problems arising from generating energy by convention method. This is because the use of the conventional energy source for drying purposes is costly and hazardous to environment. Solar drying system may be classified into direct, indirect and mixed mode.

In direct solar dryers, the air heater contains the product and solar energy passes through a transparent cover and is absorbed by the product.

Essentially, the heat required for drying is provided by radiation to the upper layers and then conducted to the product bed.

The mass of water to be removed during drying, Mw $\mathrm{kg}$

$m w=(M i-M f) /(100-M f) x$

$\mathrm{m}_{\mathrm{w}}=$ mass of water to evaporation $(\mathrm{kg})$

$\mathrm{m}_{\mathrm{i}}=$ mass of the dried product $(\mathrm{kg})$

$\mathrm{M}_{\mathrm{i}}=$ initial moisture of product $(\%, \mathrm{wb})$

$\mathrm{M}_{\mathrm{f}}=$ final moisture of product $(\%, \mathrm{wb})$

\section{Litrature Survey}

\section{Ahmet konuralp , kamil sacilik}

In this paper, During the experiments, apples were dried to the final moisture content of 11 from $82 \%$ w.b. in 1.5 days of drying in the solar tunnel dryer as compared to 2 days of drying in the open sun drying. The experimental drying data of apple slices obtained were used to fit the Page, logarithmic and Wang and Singh models, and constants of drying models tested were determined by non-linear regression analysis. Among the various models tested to represent the solar tunnel drying behaviour of organic apple, one was selected which presented best statistical indicators. Samples dried in the solar tunnel dryer were completely protected from insects, rain and dusts and the dried samples were of high quality in terms of colour and hygienic.

\section{Ahmad fudholi, kamaruzzaman sopian}

In this paper Performance analysis of solar drying system for red chili. Red chili was dried to final moisture content of $10 \%$ w.b from $80 \%$ w.b in 33 h using this system. In this study, energy and exergy analyses of the solar drying process were performed for red chili. Using the first law of thermodynamics, energy analysis was carried out to estimate the useful energy gained from the collectors. However, exergy analysis during solar drying process was estimated by applying the second law of thermodynamics. The specific energy consumption (SEC) was $5.26 \mathrm{~kW} \mathrm{~h} / \mathrm{kg}$. The values of evaporative capacity and improvement potential were from $0.13 \mathrm{~kg} / \mathrm{s}$ to $2.36 \mathrm{~kg} / \mathrm{s}$ and $0 \mathrm{~W}$ to $135 \mathrm{~W}$, respectively. The efficiencies of the solar collector, drying system, pick-up, and 
exergy were $28 \%, 13 \%, 45 \%$, and $57 \%$ respectively, at an average solar radiation of $420 \mathrm{~W} / \mathrm{m} 2$ and a mass flow rate of $0.07 \mathrm{~kg} / \mathrm{s}$

\section{Mohamed Gabbasa and Hussein A. Kazam}

In this paper, it considered A natural convection solar tunnel drier (STD) was developed for copra drying under meteorological conditions of Pollachi, India. STD reduced moisture content from 52.2\% to $8 \%$ in $57 \mathrm{~h}$ under full load and $52 \mathrm{~h}$ under half load conditions.Drying rate in bottom tray was lower (2\%) thanthat of top tray. quality of copra obtained was good (84.66\% milling copra) inn open sun dry (53\%).

\section{Gauhar a.mastekbayeva, m.Augustus leon}

A multi-product of solar tunnel dryer was fabricated based on the Hohenheim dryer design, but suitably modified to satisfy the drying requirements of small farmers and co-operatives. The collector-dryer system has been equipped with instrumentation to evaluate the performance. No load tests on the dryer, with alternate current (AC) driven fans and solar photovoltaic (PV) based direct current (DC) driven fans have been conducted. The performance of the dryer during drying of chilli has also been analysed for the two configurations. The results, shown by plotting the variation of air temperature, moisture content etc. indicate that the dryer performs better with DC/PV driven fans, as they considerably reduce the fluctuations in the drying air temperature with fluctuating solar radiation.

\section{Problem Definition}

The solar tunnel dryer consist of a solar collector, drying tunnel, and three radial flow fans to drive the moist air out of the drier. The product to be dried is placed as a single layer inside the drying tunnel.

Air entering the solar collector is heated and is forced on the products placed in the drying tunnel using two fans at the air inlet of the solar collector. For experiments with DC power from solar PV panels could be used. Metal plates are curved to be S-shaped and used as slide walls. Moreover top of the dryer is covered by transparent materials. This is paper heat air not fully circulated in the solar drier tunnel

- Increased time

- More humidity \& moisture content

- Less surface area and less focus of sun rise

\section{Proposed System \& Procedure :}

Air entering the solar collector is heated and is forced on the products placed in the drying tunnel using two fans at the air inlet of the solar tunnel collector with using added Increase fins in longitudinal to GI sheet and black coating to improve the heat rate and area more heat to dried the grapes with shoot time period and high humidity rate and moisture content in turn to increases the vapor pressure of the moisture in the product, reduces relative humidity of the air, then increases its moisture loading capacity and ensures sufficiently low equilibrium moisture content Solar energy can be used as an important and environmental compatible source of renewable energy

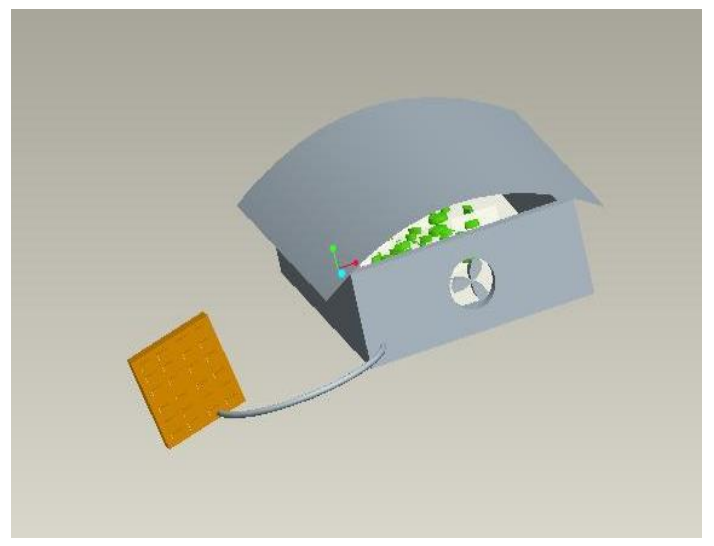

\section{Instrumentation \& Device :}

A pyranometer (Kipp \& Zonen model CM 11, accuracy $\pm 0.50 \%$ ) was placed on the top of dryer to measure solar radiation Relative humidity from ambient and in any parts of dryer were employed, used hygrometer (Electronik, model EE23, accuracy $\pm 2 \%$ ). Temperatures in the collectors, product container, air duct and ambient were measured by Thermocouple Type $\mathrm{K}$ (accuracy $\pm 0.1^{\circ} \mathrm{C}$ ). Moreover, the air speed in the dryer also measured by anemometers (Airflow, model TA5, accuracy $\pm 2 \%$ ). 
All voltage data from pyranometer, hygrometer and Thermocouple Type $\mathrm{K}$ were recorded (Yokogawa) every ten minutes. For air speed was manually monitored at 3-hour intervals during the experiment. The performance of the drier was evaluated by conducting tests at by loading with pandanus tectorius, by measuring the following parameters:

(a) radiation incident on the collector

(b) air temperatures at various locations in the collector and dryer

(c) relative humidity and weight of samples.

To measure the temperature of air at various locations of the collector and dryer, K-type thermocouples were installed at various points along the length and breadth of the solar tunnel dryer,

All temperature data were registered at an interval of ten minutes .

Drying test was started at 8:00 hours and stopped at 17:00 hours. Moreover, the sample products were also prepared and placed on product container parts and outside. 3-hour intervals, the samples were brought to weight until the end of process and they were taken in an oven to bake at $103^{\circ} \mathrm{C}$ for 24 hours.

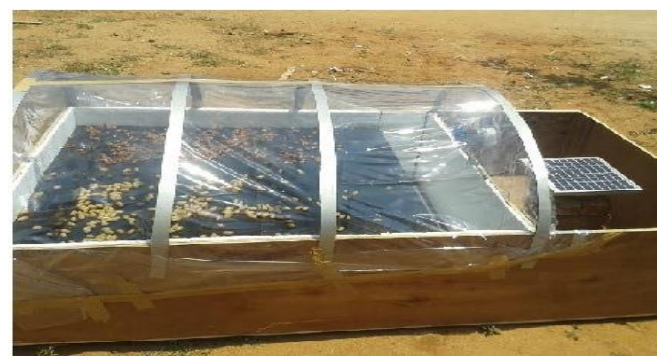

\section{Result \& Discussion}

The relative humidity values of 23 Jan 2014 to 24 Jan 2014 at 10 a.m-4p.m. were quite low, but they got increasing in the evening. This is not as seen with Figure because the humidity is the highest in the morning. 30.04 .2014
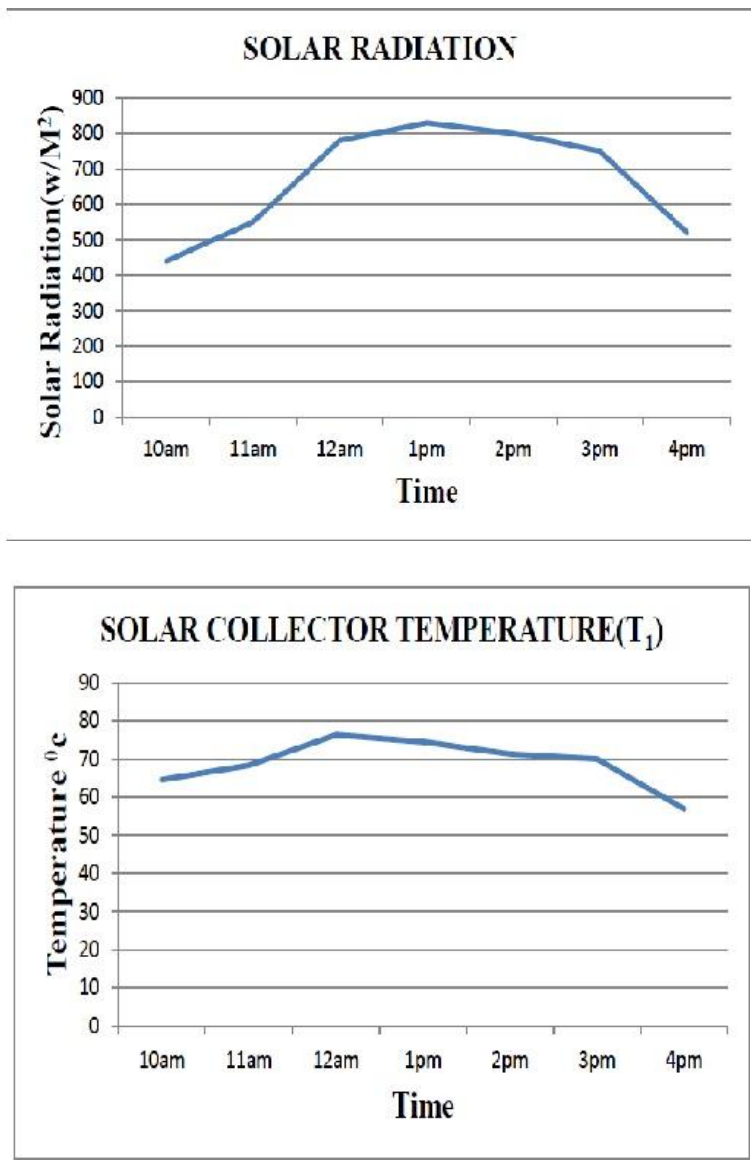

The drying rate of Grapes in the dryer is significantly higher than that of the natural sun dryer. The variations of moisture of Grapes were shown in Fig. 
After two days of drying moisture content, the remaining weight of Grapes was about $1 / 4 \mathrm{~kg}$. The quality of dried Grapes in terms of color, texture and taste is as good as high quality dried.

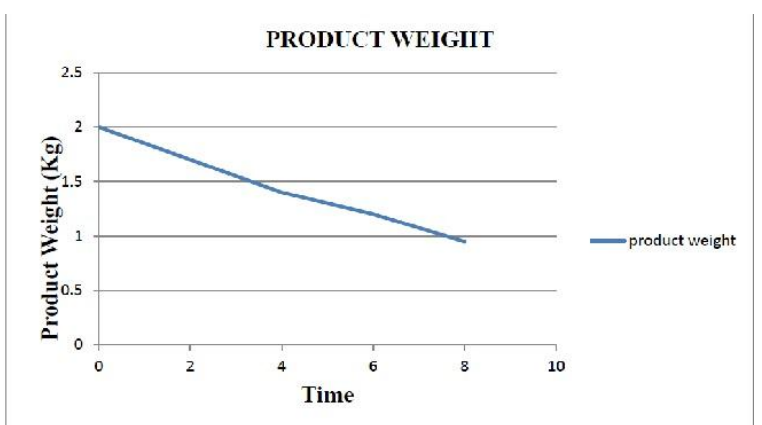

Grapes before dried on solar dryer

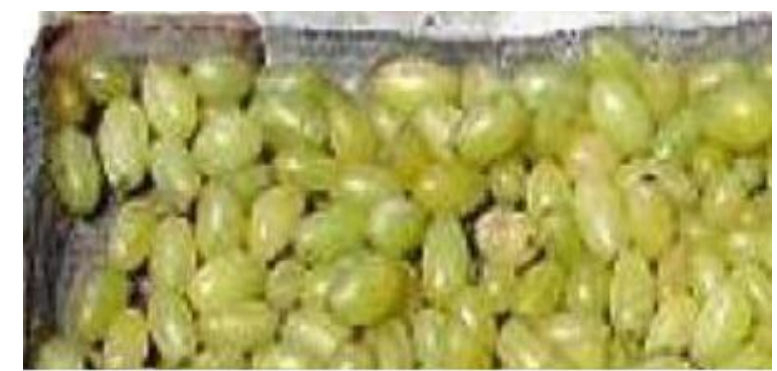

\section{Grapes after dried on solar drying}

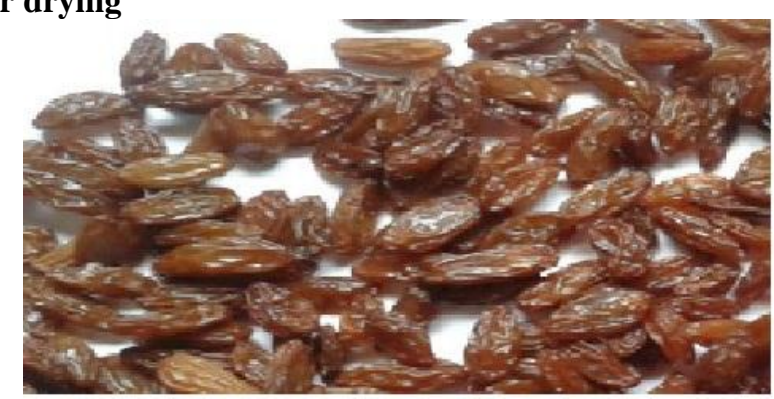

\section{Advandages:}

1.Increased production rate

2.Quickly dried all products in poor climate

3.Incrased temperature tunnel \& less humidity product

\section{References}

[1] Bolaji BO, Analysis of moisture transport in the Solar Drying of food items. The pacific J science and technology 2008; 640-646

[2] Janjai S Srisittipokakun,N.Experimental and modeling performances of a roof-integrated solar drying system for drying herbs and spices. Energy 2008; 91-103

[3] Moradi M, ZomorodianA. Thin layer solar drying of cuminum cyminum grains by means of solar carbinet dryer American-Eurasian J.Agric \& Environ sci 409-413

[4] Akpinar, E.K., 2004. Energy and exergy analyses of drying of red pepper slices in a convective type dryer. International Communications in Heat and Mass Transfer 31, 1165-1176.

[5] Bala, B. K and M. R. A. Mondol. 2001. Experimental investigation on solar drying of fish using solar tunnel dryer. Drying Technology 19 (2): 427-436. ISSN: 2222-4254.

[6] Schirmer, P., S. Janjai, A. Esper, R. Smitabhindu and W. Mühlbauer. 1996. Experimental investigation of the performance of the solar tunnel dryer for drying bananas. Renewable Energy 7 (2) : 119-129.

[7] Schirmer. P., Janjai. S., Esper. A.Smitabhindu.R., and Muhlbauer. W., Experimental investigation of the performance of the Solar Tunnel Dryer for Drying Bananas, Renewable Energy, Vol. 7, No. 2, pp. 119-129, 1996

[8] Lutz. K., Mühlbauer. W., Muller. J., and Reisinger. G., Development of Muti-purpose Solar Crop Dryer for Arid Zones, Solar and Wind Technology, 4: 417-428, 1987. 